\title{
Plato's Attitude towards Suicide in the Dialogue Crito
}

\author{
Armand A. Voinov ${ }^{1}$
}

Although the central theme of the dialogue Crito is not suicide, we consider that Plato treated this subject in the dialogue whose action is taking place three days before Socrates's death. The previous sentence is epitomising the task that this paper proposes. To assess Plato's attitude towards suicide, we must, firstly, take a brief look over the central theme of the dialogue. This first step is necessary in order for the reader to better understand the role of the dialogue in the Platonic opera. Also, in this first part, this study will try to determine if the subject of suicide is present in the dialogue, even if the characters of the dialogue are not discussing it explicitly. In this part, we will argue that the attitude towards suicide, suggested in this dialogue, belongs to Plato. Secondly, the study will concentrate both on what is stated explicitly about suicide and on what the reader can understand from what is not stated explicitly, but implicitly. Keeping in mind that the entire Platonic tradition agreed that the dialogue is about duty, the reader should expect most of the information to come from the second category: the one that does not speak explicitly about suicide. Therefore, the second part of this study will appear to the reader as an interpretation of the dialogue from the perspective of Plato's attitude towards suicide. Also, the conceptual analysis presented in the second part tries to show how and what can be deducted about Plato's attitude towards suicide.

Crito is considered a work written during Plato's youth, thus belonging to his early dialogues. This category, of early dialogues, is similar to a series of stenographies of the dialogues between Socrates, present every time, and another character. Plato visibly influenced how

\footnotetext{
${ }^{1}$ Faculty of Political Sciences, Philosophy and Communication Sciences, West University of Timisoara, Romania.
} 
we perceive the dialogues, at least from a stylistic point of view, his work being abundant in dramatic parts, almost like a theatrical play. Given that Plato is not always present in the dialogue, we can imagine either that the written dialogue is different from the spoken one, or that Plato is writing his work based on a story told by someone present at the dialogue. Thus, we can consider that Plato also interferes with the content of the dialogue. The discussions in the Socratic dialogues are usually starting from questions like "what is courage?" or "what is piety?" and others alike. Although the questions are not answered every time, Socrates's interlocutor becomes conscious about the difficulty of such questions, previously considered trivial. Two dialogues are the exception to this rule: Crito and The Apology of Socrates. These two dialogues do not have a central question that guides the discussion. In The Apology of Socrates, we encounter the narration of Socrates's trial and in Crito, we see Socrates's answer to his best friend's proposal to evade from prison. Because of Crito's proposal, the discussion develops an ethical side where the debate focuses on the legitimacy of Socrates's possible prison-breaking, and as Guțu-Maftei ${ }^{2}$ said: "the discussion between the two friends will be an attempt to decide if avoiding death and accepting any way of living is right or wrong." 3 This is why Neoplatonists considered that the dialogue is about duty, and why most readers consider this dialogue an ethical one. In his attempt to persuade Socrates to escape, Crito invokes, as an argument, the opinion of "most people" 4 about Socrates and his friends. "Most people" will think of this affair with disgrace because nobody tried to avoid this outcome. Socrates deconstructs this argument by showing that they should not care about what "most people," will think of them, declaring that he prefers to live according to what is good. In the end, Socrates uses the method of personifying the laws. He proposes to Crito a thought experiment in which the two of them, while trying to escape from prison, would meet the personified laws. From Socrates's perspective, the laws are mad at him because he accepted and defended them all his life, by words and actions, and now, because their decision is against him and his friends, he decided to ignore and defy them. Crito

2 Marta Guțu-Maftei, "Introducere" [Introduction], Platon. Dialoguri Socratice [Plato. Socratic Dialogues], ed. Cătălin Cioabă (Bucharest: Editura Humanitas, 2015), 274.

3 In the Romanian original: discuția dintre cei doi prieteni va urmări să stabilească dacă a evita moartea și a accepta orice fel de viață constituie un act drept sau nedrept.

4 "most people" has a pejorative meaning because they are not rational as stated at $44 \mathrm{~d}$. 
relinquishes, agrees with Socrates, and the final decision is to not evade from prison. "Then, Crito, let it be; and let us act in this way, since it is in this way that God leads us,"5 says Socrates at 54e.

Particular attention should be paid to the fact that Plato did not name dialogue On Duty. He named the dialogue Crito, and the subtitle On Duty was added later by other Platonists. Indeed, the main topic is the duty and to state otherwise would be a mistake that many philosophers would point out. Therefore, we propose to the reader to ignore the subtitle. If the reading of this piece from Plato starts with the presupposition that the reader will only enconter problems about justice, injustice or duty the reader will be tempted to ignore the other topics that are present in the dialogue or to subscribe them entirely to the theme of duty. Although the problem of suicide, which this study is treating, is not explicitly elaborated in this work of Plato, we consider that if such a dialogue (between Socrates and a friend of his, or more friends) happened in such a context (that of a proposal of prison-breaking) and the conclusion was not to evade, the participants to the discussion must have thought of Socrates's decision as a decision that entails suicide. Because the character is, generally speaking, the creation of the author and because Plato interfered in the content of the dialogue as well, we consider that the stance regarding suicide which is suggested in the dialogue belongs to Plato.

We agree with Guț-Maftei ${ }^{6}$ that The Apology of Socrates and Crito are works which arose from the feeling of responsibility towards a man who did not renounce his life principles. Responsibility towards a man who chose death, and chose to commit suicide instead of renouncing his life lifelong principles. Thus, the dialogue Crito can be considered Plato's attempt to explain Socrates's gesture. ${ }^{7}$ Such an attempt is also present in Phaedo. If Socrates had evaded, he would have violated the law, but this is more than a legal problem. This problem's root revolves around the point of view in which the Gods of Ancient Grece are perceived by the citizens. These Gods had memory and were vengeful. More than that,

\footnotetext{
5 Plato, "Crito", in Plato in Twelve Volumes, Vol. 1, trans. Harold North Fowler (Cambridge, MA: Harvard University Press; London: William Heinemann Ltd., 1966), http:/ / data.perseus.org/citations/urn:cts:greekLit:tlg0059.tlg003.perseus-eng1:54e (accessed December 15, 2019).

${ }^{6}$ Cf. Marta Guțu-Maftei, "Introducere”, Platon. Dialoguri Socratice, 278.

${ }^{7}$ Cf. Ulrich von Wilamowitz-Meollendorff, Platon (Berlin: Berlin Weidmann, 1920), Vol. 2, 55.
} 
the laws of the city-state are akin to the Gods. The laws which Socrates is invoking and personifying in the final part of the dialogue (54c) are forming a brotherhood with the laws from Hades realm: "We shall be angry with you while you live, and there our brothers, the laws in Hades' realm, will not receive you graciously; for they will know that you tried, so far as in you lay, to destroy us." 8 Guțu-Maftei ${ }^{9}$ wrote: "The existence of the citizen cannot be imagined outside the city-state, thus respecting the laws of the city-state is essential to his life." 10 The laws which the citizens should follow for the well-being of the city-state is a problem of significant concern for Plato, and this is reflected in his entire work, not just in the Republic or the Laws. By reading the dialogue, the reader will encounter three paragraphs in which Plato's character, Crito, is expressing his opinion: that Socrates is eager to commit suicide and this gesture of his, risks to be considered shameful. In what follows, we will analyse these three fragments keeping in mind what Jerome Eckstein ${ }^{11}$ stated, as we concur to his argument: that Socrates committed suicide, not because he took the hemlock poison with his own hands and drank it all by himself, but because he did nothing to avoid his death, and his decisions, to not act on many occasions, caused his death.

The first fragment from Plato's work, in which Crito is suggesting that Socrates' refusal to escape from prison is no different than the act of committing suicide is at 45c. The translation of Fowler is showing us how Crito is accusing Socrates of being eager $(\sigma \pi \varepsilon \dot{v} \delta \omega)$ to destroy himself: "And besides, Socrates, it seems to me the thing you are undertaking to do is not even right-betraying yourself when you might save yourself. And you are eager to bring upon yourself just what your enemies would wish and just what those were eager for who wished to destroy you." 12 The next fragment, from $45 \mathrm{~d}$ to $46 \mathrm{a}$, highlights the fact that this "absurdity" could have been avoided and that Crito is ashamed of the outcome. The verb aioxúvoual, which Fowler translates as "shamed", also means "to be dishonoured" or "to be disfigured" according to Liddell-

\footnotetext{
8 Plato, "Crito", in Plato in Twelve Volumes, Vol. 1.

${ }^{9}$ Marta Guțu-Maftei, "Introducere”, Platon. Dialoguri Socratice, 276.

${ }^{10}$ In the Romanian original: "Existența cetățeanului nu este concepută în afara $\pi 0 \lambda \iota \sigma$-ului căruia el îi aparține, astfel încăt respectarea legilor cetății devine condiția esențială a vieții acestuia."

11 Cf. Jerome Eckstein, The Death day of Socrates (New Jersey: Columbia Pub. Co., 1981).

12 Plato, "Crito", in Plato in Twelve Volumes, Vol. 1.
} 
Scott-Jones Lexicon, so definitely, Crito experiences a powerful sentiment which is expressed like this: "So I am shamed both for you and for us, your friends, and I am afraid people will think that this whole affair of yours has been conducted with a sort of cowardice on our partboth the fact that the case came before the court, when it might have been avoided, and the way in which the trial itself was carried on, and finally they will think, as the crowning absurdity of the whole affair, that this opportunity has escaped us through some base cowardice on our part, since we did not save you, and you did not save yourself, though it was quite possible if we had been of any use whatever."13 This shame, which Crito is experiencing, is also caused by Socrates's decision which he took in front of the judges. We know from The Apology of Socrates that he could have chosen to be exiled instead of the death penalty and he could also have hired a lawyer, but he did not. Crito, at 46a, insists: "Take care, Socrates, that these things be not disgraceful, as well as evil, both to you and to us."14 Like the reader would expect, this fragment is suggesting, that Socrates's decision to not oppose his death penalty is shameful. This gesture of his is considered shameful because Crito is making a distinction between the badness $(\kappa \alpha \kappa \tilde{\omega})$ of the death and the dishonouring ( $\alpha i \sigma \chi \varrho \dot{\alpha})$ part of it. Crito considers it is bad $(\kappa \alpha \kappa \tilde{\omega})$ to die, to be killed. However, to wish to be killed, which in this case is equivalent to suicide, is dishonouring ( $\alpha \mathfrak{i} \sigma \chi \varrho \dot{\alpha})$. To let yourself be killed is equivalent to suicide precisely because Crito considers it, in addition to being bad, an act of shame. If to be killed without one's allowance, as in the case of Socrates, would be considered the equivalent of being killed with allowance, the matter would have been either just about evilness, or evilness and dishonour together. Crito would not have had the reason to distinguish between a case where it is evil $(\kappa \alpha \kappa \tilde{\omega})$ and a case where it can

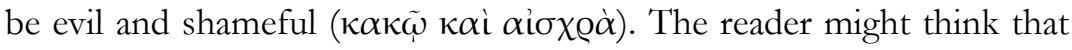
Crito considers the gesture shameful not because Socrates is committing a form of suicide, but because Socrates would not fulfil his duty towards his children, a reason also invoked at $45 \mathrm{~d}$. If Socrates would have done his duty towards his children and evaded, then, he would not have done his duty towards the laws. If Crito uses the criterion of not fulfilling a

\footnotetext{
13 Ibidem.
}

14 Ibidem. 
duty when he attributes the shame, still, Socrates would commit a dishonouring gesture. Therefore, from Crito's perspective and maybe from the perspective of the "most people," the shamefulness comes from the fact that Socrates is permitting his own execution, which becomes equivalent to suicide. This gesture of Socrates, of permitting his own execution, although may be considered a form of suicide, would be proved to not be shameful or dishonouring by Plato's further work. The dialogue Crito has then the purpose of defending Socrates's integrity by picturing Plato's teacher as a man who puts moral values above his own life. Crito would have put, just like Socrates, moral values above life, if he had used the criterion of not fulfilling the duty towards one's children. However, there are few chances for a man who befriended Socrates his entire life to simply forget about the laws and one's duty to follow them. It does not seem reasonable to invoke a duty (towards one's children) but to forget about another (towards the laws of the city-state). If Crito is using this criterion, he intentionally "forgot" about the laws, and if he were to be conscious about the laws and what the prison breaking meant, the entire dialogue would have been Socrates's answer to a sophism. The personification of the laws would have been useless when pointing out Crito's logic error would have been enough to deconstruct the argument. However, it is implausible for Crito, a friend of Socrates's and a friend of philosophy, to commit such a mistake. Also, let us not forget the fact that this is a dialogue between two characters from Plato's written work and a useless differentiation (between a case where it is evil and a case where it is evil and shameful) would have been redundant for Plato to make and to write.

Therefore, we can deduce that the shame which Crito is assigning is not based on fulfilling or not a duty, but he assigns it because Socrates's gesture might be considered a suicidal one, especially by "most people." Socrates, on the other hand, argues that he prefers to die than to live in exile. Here Guț-Maftei ${ }^{15}$ observed, "a delimitation which puts in antithesis the concept of 'just living' and the concept of 'living according to good', which implies not doing immoral actions." 16 This precept, which Socrates uses to guide his life, in the dialogue, is, actually, Plato's

\footnotetext{
15 Marta Guțu-Maftei, "Introducere”, Platon. Dialoguri Socratice, 276.

16 In the Romanian Original: "o delimitare care opune conceptului de a ,a trăi pur și simplu”, adică la întâmplare și fără norme morale statornice, pe cel de „,a trăi conform ideii de bine", deci implicit de a nu comite fapte nedrepte sau imorale."
} 
precept and not Socrates's. This argument is sustained by Xenophon's Memorabilia, in which he presents Socrates as a follower of the law of retaliation: an eye for an eye. In Xenophon's work, when Socrates speaks to Critobulus, he says: "you have made up your mind that a man's virtue consists in outdoing his friends in kindness and his enemies in mischief; then I think you will find me a useful companion in the quest of good friends." 17 From the incursion made so far, in the Platonic dialogue Crito, we can notice that suicide is discussed in correlation with the duty towards the laws of the city-state and with the good caused by following or not following them. These two former themes are the subject which constitutes the most prominent part of the work, and suicide is a secondary topic. The reader can observe that Plato tried, on one hand, to prove Socrates's correctness towards the law, and on the other hand, the reasons for which someone (anyone) should respect the law, even if it means to kill oneself. Also, the reader can observe no separation between ethics and politics because, from Plato's perspective, at least in this dialogue, they are functioning together. For Plato, it was necessary to simultaneously prove the two facts (Socrates's correctness and the fact that the laws are good in themselves) because he could not have had developed his later work, like the Republic or the Laws. For his works to be consistent it was necessary that both Socrates the teacher, and Socrates the character, would respect and promote the law. Plato's work could not have been well received by the citizens if the objections of learning from an outlaw had been valid. Alternatively, if the main character of his opera would not have respected the law, Plato would have contradicted himself. Thus, by using suicide as a pretext to prove Socrates's correctness and the primacy of the laws, Plato showed his opinion about it.

The first conclusion that the reader can draw is that Plato, generally,

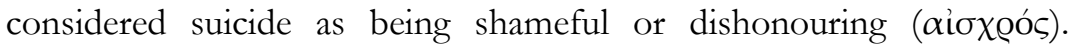
However, there is one exception: when the good is above life. If the suicide is not in accordance with the Idea of Good, then it is a shameful

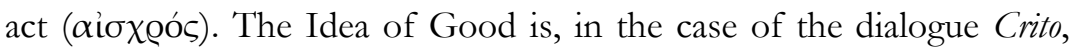
equivalent with respecting the duty one has towards the laws of the city-

17 Xenofon, "Memorabilia", in Xenophon in Seven Volumes, Vol. 4, trans. E. C. Marchant (Cambridge, MA, Harvard University Press; London, William Heinemann Ltd.,1923), http://data.perseus.org/citations/urn:cts:greekLit:tlg0032.tlg002.perseus-en g1:2.6.35 (accessed December 15, 2019). 
state, which, in turn, are related to Gods and Hades's realm as is mentioned at 54c. Secondly, we can conclude that, from Plato's perspective, Socrates's gesture is not morally blameworthy precisely because Socrates is respecting the laws of the city-state, which are good in themselves, as the entire dialogue tried to prove. By showing this, Plato dismisses Socrates's shame. If Socrates's gesture would not have had participated to the Idea of Good, then it would have been shameful indeed, like Crito suggested. Concisely, the suicide which is an exception from shame is the one that obeys the laws - and this is our third conclusion. Socrates is respecting the law and does not evade prison, choosing to kill himself. The shame of which Crito and "most people" are accusing Socrates is abolished and thus, in Plato's vision, the suicide which is ordered by the city-state, according to its laws, is morally, and, of course, legally accepted. Also, the laws from the Hades's realm are not mad at Socrates because he respected their brothers, the laws of the citystate. Of course, all these conclusions are indicating that Plato distinguished between death and suicide.

\section{References}

Carrick, Paul. Medical Ethics in the Ancient World. Washington, D.C: Georgetown University Press, 2001.

Cholbi, Michael. "Suicide". In The Stanford Encyclopedia of Philosophy (Fall 2017 Edition), ed. Edward N. Zalta. https://plato.stanford.edu /archives/fall2017/entries/suicide/ (accessed December 15, 2019).

Colțescu, Viorel. Istoria filosofiei: epoca veche, medie și modernă [The History of Philosophy: Old Epoch, Middle and Modern]. Timișoara: Editura universității de vest, 2002.

Coplestone, Frederick. A History of Philosophy, Vol 1: Greece and Rome. Doubleday, 1993.

Eckstein, Jerome. The Death day of Socrates. New Jersey: Columbia Pub. Co., 1981.

Gagarin, Michael (ed.). The Cambridge Companion to Ancient Greek Law. Cambridge: Cambridge University Press, 2005.

Garrison, Elise. "Attitudes toward Suicide in Ancient Greece." Transactions of the American Philological Association (1974) 121 (1991).

Guthrie, W. K. C. A History of Greek Philosophy. Cambridge: Cambridge University Press, 1992. 
Guțu-Maftei, Marta. "Introducere" [Introduction]. In Platon, Dialoguri Socratice [Plato. Socratic Dialogues]. Bucharest: Humanitas, 2015.

Irwin, Terecnce. Plato's Ethics. Oxford: Oxford University Press, 1995.

Jouanna, Jacques. "Air Miasma And Contagion In The Time Of Hippocrates And The Survival Of Miasmas In Post-Hippocratic Medicine (Rufus Of Ephesus, Galen And Palladius)." In Greek Medicine from Hippocrates to Galen, ed. Philip van der Ejik, 121-136. Leiden \& Boston: Brill, 2012.

Kraut, Richard, ed. A Cambridge Companion to Plato. Cambridge: Cambridge University Press, 1992.

Liddell, Henry George and Robert Scott. Comp. Greek-English lexicon (LSJ). Oxford: Clarendon Press, 1996.

Naiden, F.S. "The Sword Did It: A Greek Explanation for Suicide." Classical Quarterly, vol. 65:1 (2015).

Parker, Robert. Miasma: Pollution and Purification in Early Greek Religion. Oxford: Oxford University Press, 1983.

Plato. The Apology of Socrates. Translated by Harold North Fowler. In Plato in Twelve Volumes. Cambridge, MA: Harvard University Press; London: William Heinemann Ltd., 1966. http://data.perseus.org / citations/urn:cts:greekLit:tlg0059.tlg002.perseus-eng1:17a (accessed December 15, 2019).

- The Apology of Socrates. Ed.: John Burnet. Oxford: Oxford University Press, 1903. http://data.perseus.org/citations/urn:cts:greekLit:tlg00 59.tlg002.perseus-grc1:17a (accessed December 15, 2019).

- Crito. Translated by Harold North Fowler. In Plato in Twelve Volumes. Cambridge, MA: Harvard University Press; London: William Heinemann Ltd., 1966. http:/ / data.perseus.org/citations/urn:cts:gre ekLit:tlg0059.tlg003.perseus-eng1:43a (accessed December 15, 2019).

—. Crito. Ed. John Burnet. Oxford: Oxford University Press, 1903. http:/ / data.perseus.org/citations/urn:cts:greekLit:tlg0059.tlg003.per seus-grc1:43a (accessed December 15, 2019).

- Phaedo. Translated by Harold North Fowler. In Plato in Twelve Volumes. Cambridge, MA: Harvard University Press; London: William Heinemann Ltd., 1966. http://data.perseus.org/citations/urn:cts:gre ekLit:tlg0059.tlg004.perseus-eng1:57a (accessed December 15, 2019).

—. Phaedo. Ed. John Burnet. Oxford: Oxford University Press, 1903. http:/ / data.perseus.org/citations/urn:cts:greekLit:tlg0059.tlg004.per seus-grc1:57a (accessed December 15, 2019). 
- Laws. Translated by R. G. Bury In Plato in Twelve Volumes. Cambridge, MA: Harvard University Press; London: William Heinemann Ltd., 1967 \& 1968. http://data.perseus.org/citations / urn:cts:greekLit:tlg0059.tlg034.perseus-eng1:1.624 (accessed Dec. 15, 2019).

—. Laws. Ed. John Burnet. Oxford: Oxford University Press, 1903. http://data.perseus.org/citations/urn:cts:greekLit:tlg0059.tlg034.per seus-grc1:1.624 (accessed December 15, 2019).

- Republic. Translated by Paul Shorey. In Plato in Twelve Volumes. Cambridge, MA: Harvard University Press; London: William Heinemann Ltd., 1966. http:/ / data.perseus.org/citations/urn:cts:gre ekLit:tlg0059.tlg030.perseus-eng1:1.327a (accessed December 15, 2019).

—. Republic. Ed. John Burnet. Oxford: Oxford University Press, 1903. http:/ / data.perseus.org/citations/urn:cts:greekLit:tlg0059.tlg030.per seus-grc1:1.327a (accessed December 15, 2019).

Tarrant. Middlesex: Penguin Books, 1993.

Voinov, Armand A. "Plato's Attitude towards Suicide." MA diss., West University of Timișoara, 2019. 